\title{
Temporal variation in size at maturity of the snail Zidona dufresnei from the southwestern Atlantic Ocean after ten years of fishery exploitation
}

\author{
Eugenia Maria Torroglosa ${ }^{1}$, Juliana Giménez ${ }^{1,2, *}$ \\ ${ }^{1}$ Laboratorio de Invertebrados I, Departamento de Biodiversidad y Biología Experimental, \\ Facultad de Ciencias Exactos y Naturales, Universidad de Buenos Aires, Int. Güiraldes 2160, \\ Ciudad de Buenos Aires C1428EGA, Argentina \\ ${ }^{2}$ CONICET, Av. Rivadavia 1917, Ciudad de Buenos Aires C1033AAI, Argentina
}

\begin{abstract}
The snail Zidona dufresnei is a marine resource that has been continually exploited by trawling over the past $20 \mathrm{yr}$. Although research into this fishery started $10 \mathrm{yr}$ ago, no regulations have been implemented to date. In the present study, the histologically estimated size at maturity of both sexes of $Z$. dufresnei was found to be $131 \mathrm{~mm}$ for females and $128 \mathrm{~mm}$ for males. These values are lower than those determined in 1999 for Z. dufresnei in the same fishing area. In females, significant differences in size at first maturity were found between 1999 and 2009 in the size classes 121 to $150 \mathrm{~mm}$ and 151 to $180 \mathrm{~mm}$. In males, significant differences between years were found in the size class 121 to $150 \mathrm{~mm}$. This is the first report of changes in the size at first maturity of marine snails subjected to fishery exploitation. Effects of $Z$. dufresnei reproductive cycle, growth rate, size at maturity and population management should be taken into account in $Z$. dufresnei fishery.
\end{abstract}

KEY WORDS: Size at maturity $\cdot$ Exploited population $\cdot$ Gastropod $\cdot$ Temporal variation $\cdot$ Size selection

\section{INTRODUCTION}

Fishing is a sorting process that selectively removes individuals and the genetic changes associated with fishing have become known as fisheries-induced evolution (Conover et al. 2005). The intense selection differentials imposed by many fisheries may drive the evolution of life history traits (Hutchings 2005, Brown et al. 2008). The decrease in size at maturity observed in several commercially exploited fish stocks may be due to fisheries-induced evolutionary changes (Ernande et al. 2004, Morita \& Fukuwaca 2007, Sattar et al. 2008). For example, size at maturity of Solea solea decreased from $286 \mathrm{~mm}$ in 1960 to $246 \mathrm{~mm}$ in 2002 (Mollet et al. 2007), and in the Japanese chum Oncorhynchus keta size at maturity has decreased by about $50 \mathrm{~mm}$ since the 1960s (Eggers et al. 2003). This should favor small-maturing genotypes as their traits become more common in the population (Law 2000, Hutchings $\&$ Baum 2005). However, increased costs of reproduc- tion associated with early maturation result in higher natural mortality (Landers et al. 2001, Conover et al. 2005, Hutchings 2005). High fishing mortality and size-selective fishing are the factors that drive most fisheries-induced evolution.

Over the last few decades, the volutid snail Zidona dufresnei (Donovan, 1823) has been subjected to unregulated commercial exploitation. Yields of adults are estimated to be $1300 \mathrm{t}$ of flesh $\mathrm{yr}^{-1}$, with most landings taking place at the harbors of Mar del Plata in Argentina and La Paloma in Uruguay (Ministerio de Agricultura, Ganaderia y Pesca. www.minagri.gob.ar/ SAGPyA/pesca/index.php). This species inhabits the western coast of the southern Atlantic Ocean, at 35 to $60 \mathrm{~m}$ depth on sandy bottoms, from Río de Janeiro, Brazil $\left(22^{\circ} \mathrm{S}\right)$ to San Matías Gulf, Argentina $\left(42^{\circ} \mathrm{S}\right)$ (Kaiser 1977). Z. dufresnei is a temperate species, spawning in austral spring and summer (Giménez \& Penchaszadeh 2002). The potential lifespan of $Z$. dufresnei in the Mar del Plata region is $>17 \mathrm{yr}$, maturation 
starts at an age of $\sim 8$ to $9 \mathrm{yr}$ and the growth rate is slow (Giménez et al. 2004). But the development of management strategies is hampered by the lack of information on the population dynamics of this resource.

On this basis, the Argentine and Uruguayan fisheries of Zidona dufresnei are likely to be seriously endangered by high levels of exploitation (Giménez et al. 2005). The objective of this study is to determine histologically the size at first maturity and the mature proportion of $Z$. dufresnei and to compare the obtained values with those reported by Giménez \& Penchaszadeh (2003) for the same population at the same location 10 yr ago.

\section{MATERIALS AND METHODS}

Snail collection. Specimens of Zidona dufresnei were collected monthly during the reproductive period between October 2008 and March 2009. 265 specimens, including males and females, were caught by bottom trawling in the Mar del Plata area, Argentina $\left(38^{\circ} 20^{\prime} \mathrm{S}\right.$ $57^{\circ} 37^{\prime} \mathrm{W}$ ) at depths of 40 to $60 \mathrm{~m}$ (Fig. 1). Each snail was measured with vernier calipers at a precision of $1 \mathrm{~mm}$, and weighed (wet weight without shell) at a precision of $0.1 \mathrm{~g}$.

Gonadal maturity. The gonad, which is peripheral to the digestive gland and occupies the upper part of the spire, was removed and fixed in Bouin's solution for $18 \mathrm{~h}$. A medial portion of the preserved gonads was dehydrated in ethanol, embedded in paraffin wax, and sectioned at $6 \mu \mathrm{m}$. The sections were stained with hematoxylin and eosin (H\&E). Criteria used for determining gonadal maturity were the existence of spermatozoa in the spermatic tubules for males and the presence of oocytes undergoing vitellogenesis for females, as suggested by Giménez \& Penchaszadeh

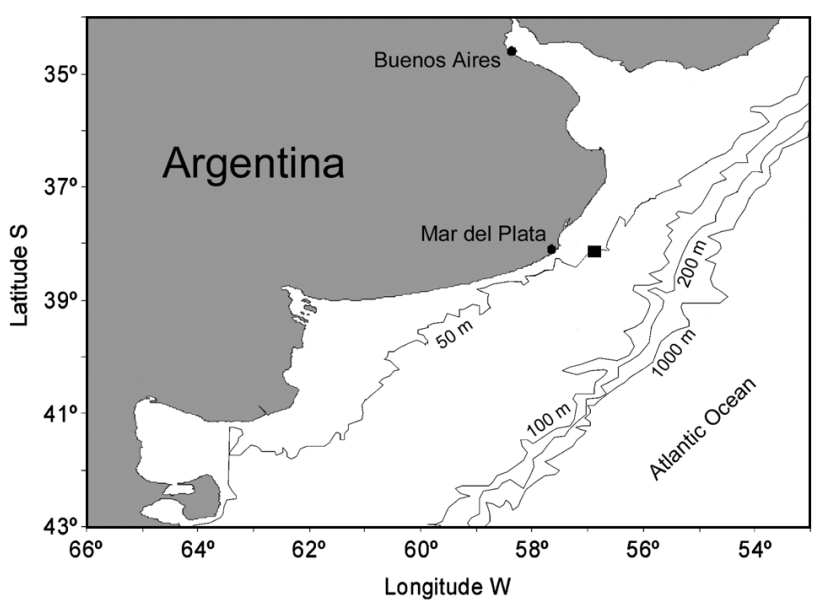

Fig. 1. Fishing location (匹), Mar del Plata ( $\left.38^{\circ} 20^{\prime} \mathrm{S}, 57^{\circ} 37^{\prime} \mathrm{W}\right)$, Argentina
(2003). Photographs of histological sections were taken using a Zeiss Axiostar microscope with a digital camera. We determined the percentage of mature females and males in this population.

Size at onset of maturity. The percentages of mature females and males in each $10 \mathrm{~mm}$ size class (snail shell length,) from the total individuals in each size class were plotted against shell length and then fitted, using a nonlinear modeling procedure, to the logistic equation.

$$
P_{\mathrm{m}}=\mathrm{a} / 1+\left(\mathrm{SL} / \mathrm{SL}_{0}\right)^{b}
$$

where $P_{\mathrm{m}}$ is the proportion of mature females or mature males, SL is snail shell length, and $\mathrm{SL}_{0}, a$ and $b$ are constants. The shell length at which $50 \%$ of the gonads are mature is defined as the size at first marurity $\mathrm{SL}_{50}$.

Data analysis. Chi-square analyses of heterogeneity were performed to compare the proportions of males and females that were mature and immature for size classes between 90 to $180 \mathrm{~mm}$.

The proportions of mature and immature individuals in 240 specimens obtained by the authors in 1999 (including females and males in size classes between 90 and $210 \mathrm{~mm}$ ) were compared to the proportions that were mature and immature in the 2009 population. Analyses of heterogeneity between years in each $30 \mathrm{~mm}$ (SL) size class were done for the size classes between 90 to $180 \mathrm{~mm}$. All statistical analyses were performed using STATISTICA 6.0.

\section{RESULTS}

A total of 265 snails were sexed with sizes ranging from 97 to $210 \mathrm{~mm}$ SL. The histological examination showed immature and mature females. In immature females, the ovaries were undeveloped, lacking oocytes and oogenic stages (Fig. 2A). Mature females had developing ovaries, with growing oocytes and vitellogenic oocytes (Fig. 2B).

Gonadal maturity in males was determined by whether stages of spermatogenesis, including spermatozoa, could be identified within the spermatic tubules. Males lacking developing cells were considered immature (Fig. 2C). Testes of mature males exhibited all stages of spermatogenesis and the presence of mature spermatozoa (Fig. 2D). The size at maturity estimated graphically, was found to be $131 \mathrm{~mm}$ for females and $128 \mathrm{~mm}$ for males. The relationships between the percentages of females and males with mature gonads and SL are shown in Fig. 3; each size class included a total of 10 to 17 mature and immature individuals. The parameters of the fitted logistic equations to describe the onset of maturity are shown in Table 1.

The Chi-square analysis showed significant differences in the proportion of mature females in the 

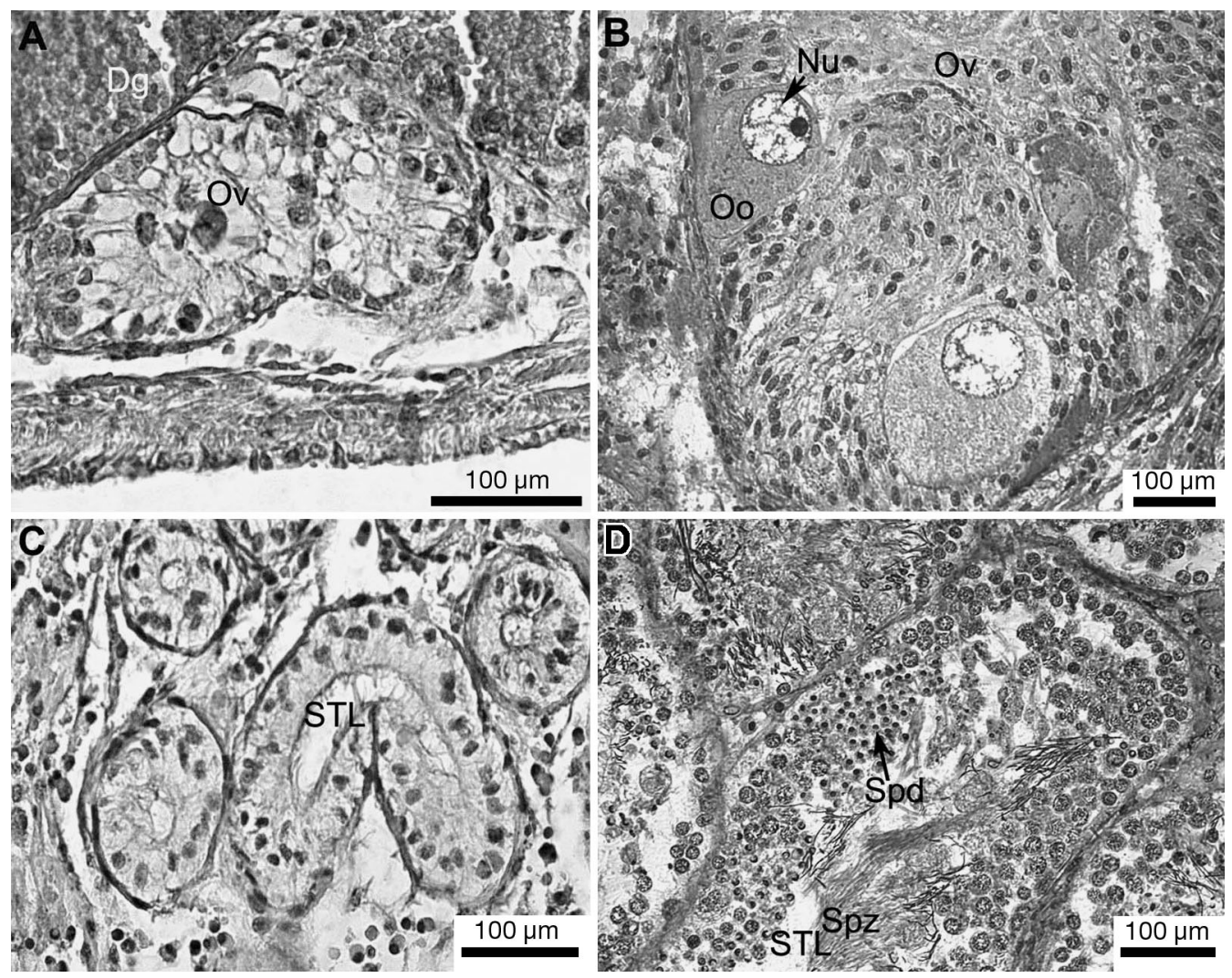

Fig. 2. Zidona dufresnei. (A) Immature ovary of a $13.8 \mathrm{~cm}$ shell length (SL) female; (B) mature ovary of a $16.8 \mathrm{~cm}$ SL female; (C) immature testis of a $12.1 \mathrm{~cm}$ SL male; (D) mature testis of a $18.3 \mathrm{~cm}$ SL male. Images show the digestive gland (Dg), growing oocytes $(\mathrm{Oo})$, nucelus $(\mathrm{Nu})$, ovary $(\mathrm{Ov})$, spermatid $(\mathrm{Spd})$, spermatozoa $(\mathrm{Spz})$ and spermatogenic tubule lumen (STL)

population between 1999 and 2009 in the size classes 121 to $150 \mathrm{~mm}$ (30 females 1999; 38 females 2009; $\mathrm{p}<0.001$ ) and 151 to $180 \mathrm{~mm}$ (30 females $1999 ; 34$ females 2009; $\mathrm{p}<0.001$ ). There was also a significant difference in the proportion of mature males in the population between years in the size class 121 to

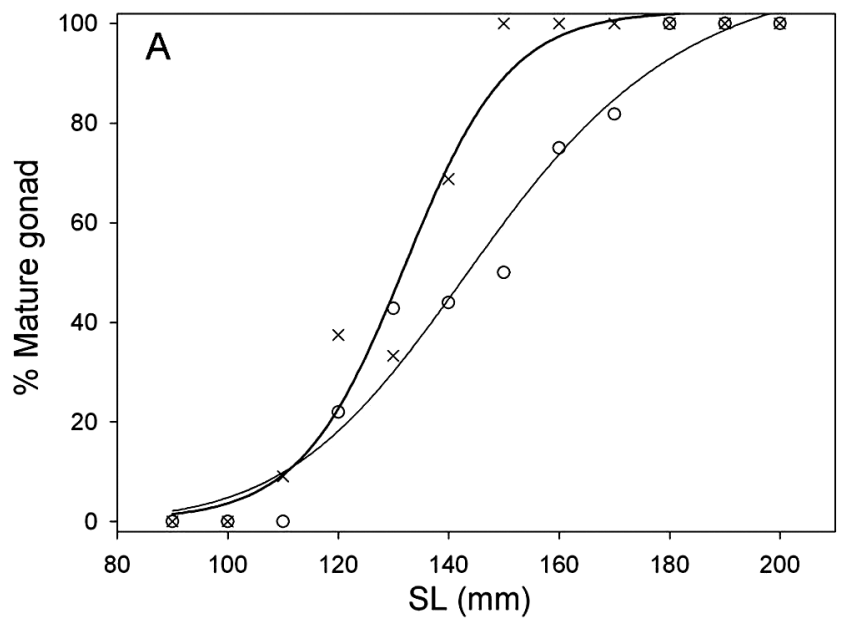

150 mm (30 males 1999; 32 males 2009; $\mathrm{p}<0.001)$. For sizes longer than $180 \mathrm{~mm}$, all specimens were mature. In size classes between 121 and $180 \mathrm{~mm}$ in 2009, a non significant difference in the proportion of males and females was found (62 males 2009; 69 females 2009; $\mathrm{p}>0.01)$.

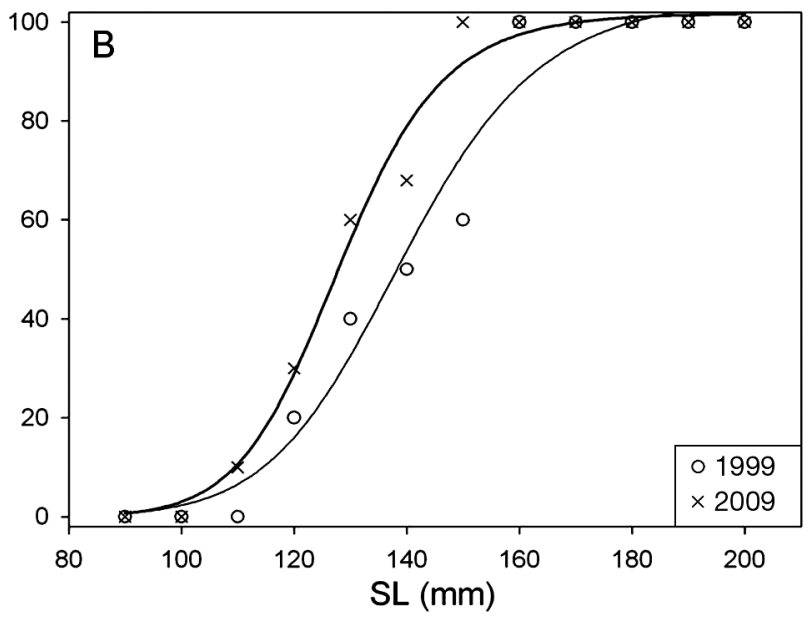

Fig. 3. Zidona dufresnei. $\mathrm{SL}_{50}$ logistic curves for the proportion of mature gonads, determined by histological criteria, as a function of shell length: (A) mature females $(n=84) ;(B)$ mature males $(n=90)$ 
Table 1. Zidona dufresnei. Parameters and coefficient of determination $\left(\mathrm{R}^{2}\right)$ for logistic function $P_{\mathrm{m}}=a / 1+\left(\mathrm{SL} / \mathrm{SL}_{0}\right)^{b}$ fitted data for each sex and both years

\begin{tabular}{|llccccc|}
\hline Year & Sex & $\mathrm{n}$ & $a$ & $b$ & $\mathrm{SL}_{0}$ & $\mathrm{R}^{2}$ \\
\hline 2009 & Females & 133 & 103.68 & -13.53 & 131 & 0.99 \\
& Males & 132 & 101.81 & -14.02 & 128 & 0.99 \\
1999 & Females & 120 & 111.41 & -8.02 & 147 & 0.99 \\
& Males & 120 & 105.43 & -11.41 & 139 & 0.98 \\
\hline
\end{tabular}

\section{DISCUSSION}

The size at first maturity of Zidona dufresnei has decreased compared with the values reported $10 \mathrm{yr}$ ago. Giménez \& Penchaszadeh (2003) recorded a first maturity size of $157 \mathrm{~mm}$ SL for females and $150 \mathrm{~mm}$ SL for males in catches from the year 1999 in the Mar del Plata area. In the present study, performed after $10 \mathrm{yr}$ of fishery exploitation, maturity was reached at lower size for females and males.

This phenomenon has been described for many fish species subjected to commercial exploitation (Ishida et al. 1993, Helle \& Hoffman 1995, Kaev 1999). However, there is little information on fisheries-induced evolution for invertebrates. Ignorance of life history traits and a lack of time series data contributes to the lack of management of some invertebrate fisheries (Linnane et al. 2009). Melville-Smith \& de Lestang (2006) reported that females of the western rock lobster Panulirus cygnus have been undergoing variation in size at maturity over the last 30 yr. Landers et al. (2001) found that size at sexual maturity of female lobsters (Homarus americanus) had recently decreased, but it is unclear whether the change was caused by density dependent factors, environmental factors, or a combination of both. In the Tanner crab Chionoecetes bairdi, Zheng (2008) found a decrease in the size of females at first maturity, but causes for temporal changes are not completely understood. There is no available information about similar traits, such as fecundity and size at first maturity, and their change over time for mollusk or gastropod fisheries.

For many benthic invertebrate fisheries, a series of measures have been established to achieve sustainability objectives. For example, minimum legal size is a widely accepted management tool in fisheries. Giménez \& Penchaszadeh (2003) suggested a minimum capture size of $160 \mathrm{~mm}$ SL for Zidona dufresnei as a management tool. However, the minimum legal size is below the size at first maturity for many species, such as Panulirus cygnus (Melville-Smith \& de Lestang 2006) and the rock lobster Jasus edwarsii (Linnane et al. 2009). In Chile, the main gastropod fishery is the muricid Concholepas concholepas. It is a very impor- tant economic resource for the artisanal fishery. During recent decades various management strategies (including closure of the fishery) have been implemented in response to changes in catches of C. concholepas to achieve sustainable levels of exploitation (Leiva \& Castilla 2002). In Chile, the most important management and conservation tools include the regulation of extraction and processing of benthic resources, the demarcation of areas for exploitation, and designation of marine protected areas.

The total annual weight of Zidona dufresnei landed has decreased by $90 \%$ (Ministerio de Agricultura, Ganaderia y Pesca. www.minagri.gob.ar/SAGPyA/pesca/ index.php), from $1300 \mathrm{t}$ in 1997 to $100 \mathrm{t}$ in 2009 (Fig. 4). $Z$. dufresnei is captured all year round, even during the reproductive season from September to December (Giménez \& Penchaszadeh 2002). In the same period, our results indicate the median size at which males and females in the population become mature has declined, and the proportion of mature individuals has increased

These changes may be a response to resource depletion, caused by permanent fishing of a resource with a slow growth rate (it may take as long as 10 yr to reach maturity) (Giménez et al. 2004). Environmental conditions for Zidona dufresnei remained much the same between 1999 and 2009. The temperature at $50 \mathrm{~m}$ depth was constant, and no pollutants were registered. No hydrographical change was found, other than damage due to the bottom trawling. However, changes due to bottom trawling could decrease food availability. Owing to its predatory lifestyle and large size, $Z$. dufresnei is likely to be affected.

According to Conover et al. (2009), evolutionary responses to the long-term exploitation of individuals from a population may include reduction in body size, age at maturation, and productivity. The Zidona dufresnei population from Mar del Plata may be

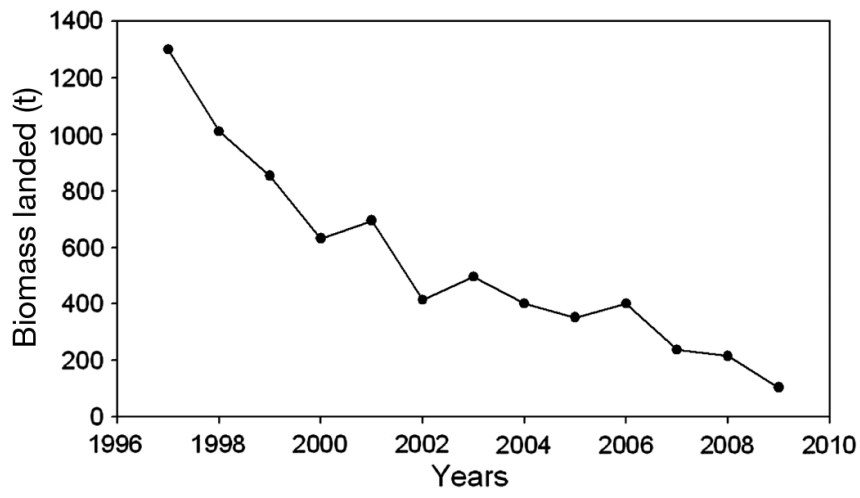

Fig. 4. Zidona dufresnei. Historical records of mean annual catch biomass (t), Mar del Plata. Ministerio de Agricultura, Ganaderia y Pesca. www.minagri.gob.ar/SAGPyA/pesca/index.php 
undergoing this process according to present results. However, evolutionary changes were reversible for populations of the silverside fish Menidia menidia, which showed an increased growth rate after the implementation of protective measures (Conover et al. 2009). Based on our follow-up study results, we suggest that $Z$. dufresnei fisheries should be regulated with a minimum catch size of $180 \mathrm{~mm}$ SL for females and males. This way, only mature specimens will be caught. We also recommend a closed fishery season for $Z$. dufresnei during the reproductive season from September to January. $Z$. dufresnei is a vulnerable economic resource at risk of suffering over-exploitation. After $10 \mathrm{yr}$ of continuous fisheries of $Z$. dufresnei, there is enough evidence to warrant implementing these recommendations.

Acknowledgments. Studies have been conducted in accordance with institutional and national guidelines concerning the use of animals in research and the sampling. We are grateful to Jennifer Antonides for her help with the English version and Analía Perez for her suggestions. This work was partially supported by CONICET PIP 2788 and UBACyT $\mathrm{X} 171$.

\section{LITERATURE CITED}

Brown CJ, Hobda AJ, Ziegler PE, Welsford DC (2008) Darwinian fisheries science needs to consider realistic fishing pressures over evolutionary time scales. Mar Ecol Prog Ser 369:257-266

- Conover DO, Arnott SA, Walsh MR, Munch SB (2005) Darwinian fishery science: lessons from the Atlantic silverside (Menidia menida). Can J Fish Aquat Sci 62:730-737

Conover DO, Munch SB, Arnott SA (2009) Reversal of evolutionary downsizing caused by selective harvest of large fish. Proc Biol Sci 276:2015-2020

Eggers DM, Irvine J, Fukuwaka M, Karpenko V (2003) Catch trends and status of North Pacific salmon. N Pac Anadromous Fish Comm Doc 723, Revision 2

Ernande B, Dieckman U, Heino M (2004) Adaptive changes in harvested populations: plasticity and evolution of age and size at maturation. Proc Biol Sci 271:415-423

Giménez J, Penchaszadeh PE (2002) Reproductive cycle of Zidona dufresnei (Caenogastropoda: Volutidae) from the southwestern Atlantic Ocean. Mar Biol 140:755-761

Giménez J, Penchaszadeh PE (2003) Size at first sexual maturity in Zidona dufresnei (Caenogastropoda: Volutidae) of the south-western Atlantic Ocean (Mar del Plata, Argentina). J Mar Biol Assoc UK 83:293-296

Giménez J, Brey T, Mackensen A, Penchaszadeh PE (2004) Age, productivity and mortality of the prosobranch snail

Editorial responsibility: Francesco Patti, Ischia, Italy
Zidona dufresnei (Donovan, 1823) in the Mar del Plata area, south-western Atlantic Ocean. Mar Biol 145:707-712

Giménez J, Lasta M, Bigatti G, Penchaszadeh P (2005) Exploitation of the volute snail Zidona dufresnei in Argentine waters, southwestern Atlantic Ocean. J Shellfish Res 24:1135-1140

Helle JH, Hoffman MS (1995) Size decline and older age at maturity of two chum salmon Oncorhynchus keta stocks in western North America, 1972-92. Publ Spec Can Sci Halieut Aquat 121:245-260

> Hutchings JA (2005) Life story consequences of overexploitation to population recovery in Northwest Atlantic cod (Gadus morhua). Can J Fish Aquat Sci 62:824-832

Hutchings JA, Baum JB (2005) Measuring marine fish biodiversity: temporal changes in abundance, life history and demography. Phil Trans R Soc B 360:315-338

Ishida Y, It S, Kaeriyama M, McKnnell S, Nagasawa K (1993) Recent changes in age and size of chum salmon Oncorhynchus keta in the North Pacific Ocean and possible causes. Can J Fish Aquat Sci 50:290-295

Kaev AM (1999) Dynamics of some biological indexes of Oncorhynchus keta in connection whit the formation of its numbers. J Ichthyol 39:642-651

Kaiser P (1977) Beiträge zur Kenntnis der Voluten (Mollusca) in argentinisch-brasilianischen Gewässern (mit der Beschreibung zweier neuer Arten). Mitt Hambg Zool Mus Inst 74:11-26

Landers DF, Keser M, Saila SB (2001) Changes in female lobster (Homarus americanus) size at maturity and implications for the lobster resource in Long Island Sound, Connecticut. Mar Freshw Res 52:1283-1290

- Law R (2000) Fishing, selection, and phenotypic evolution. ICES J Mar Sci 57:659-668

> Leiva GE, Castilla JC (2002) A review of the world marine gastropod fishery: evolution of catches, management and the Chilean experience. Rev Fish Biol Fish 11:283-300

Linnane A, Shane P, Hawthorne P, Hoare M (2009) Spatial differences in size of maturity and reproductive potential between inshore and offshore fisheries for southern rock lobster (Jasus edwarsii) in South Australia. Fish Res 96: 238-243

Melville-Smith R, de Lestang S (2006) Spatial and temporal variation in the size al maturity of the western rock lobster Panulirus cygnus George. Mar Biol 151:183-195

> Mollet FM, Kraak SBM, Rijnsdorp AD (2007) Fisheriesinduced evolutionary changes in maturation norms in North Sea sole Solea solea. Mar Ecol Prog Ser 351: 189-199

Morita K, Fukuwaka MA (2007) Why age and size at maturity have changed in Pacific salmon. Mar Ecol Prog Ser 335: 289-294

Sattar SA, Jogensen C, Fiksen $\varnothing$ (2008) Fisheries-induced evolution of energy and sex allocation. Bull Mar Sci 83: $235-250$

Zheng J (2008) Temporal changes in size at maturity and their implications for fisheries management for Eastern Bering Sea Tanner Crab. J Northw Atl Fish Sci 41:137-149

Submitted: April 26, 2010; Accepted: October 27, 2010

Proofs received from author(s): December 7, 2010 